
NA PRESENÇA DE POLÍMEROS À BASE DE PLANTAS

\title{
QUERCETIN STABILITY UNDER MECHANICAL STRESS IN THE PRESENCE OF PLANT-BASED POLYMERS
}

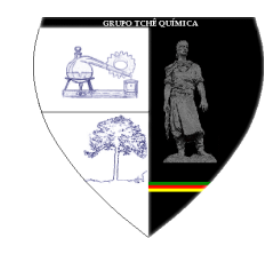

\section{УСТОЙЧИВОСТЬ КВЕРЦЕТИНА К МЕХАНИЧЕСКОМУ ВОЗДЕЙСТВИЮ В ПРИСУТСТВИИ ПОЛИМЕРОВ РАСТИТЕЛЬНОГО СЫРЬЯ}

\author{
ORLOV Denis V. ${ }^{1 *}$; LOMOVSKIY Igor O. ${ }^{2}$; LOMOVSKIY Oleg I. ${ }^{3}$ \\ $1,2,3$ Institute of Solid State Chemistry and Mechanochemistry, Siberian Branch of the Russian Academy of \\ Sciences, 18 Kuteladze str., 630128 Novosibirsk, Russia \\ (phone: +7 9134608900 ) \\ ${ }^{*}$ Corresponding author \\ e-mail: denorlov_25@mail.ru
}

Received 02 November 2016; received in revised form 10 November 2016; accepted 01 December 2016

\section{RESUMO}

Neste trabalho, consideramos a resistência ao estresse mecânico da quercetina - 3, 3 ', 4', 5, 7 pentahidroxiflavona em substância pura, em uma mistura de quercetina sólida cristalina com polímeros à base de plantas e adsorvida em polímeros à base de plantas. Os polímeros à base de plantas foram produzidos por remoção química passo a passo de componentes de material vegetal. O mais estável ao tratamento da máquina é a quercetina adsorvida em componentes de polímero de celulose, que retêm a textura do tecido original da planta. A capacidade de aumentar a estabilidade da quercetina no processo de tratamento mecânico muda de hemicelulose através de celulose amorfa para celulose cristalina. A adsorção em celulose cristalina e amorfa, que não retém a morfologia do material vegetal, provoca a redução da estabilidade da quercetina adsorvida a um tratamento mecânico subsequente. A quercetina que é adsorvida em lenhina polifenólica à base de polímero é a menos resistente ao tratamento mecânico. A compreensão da interação da quercetina e de outros compostos fenólicos com matrizes à base de celulose pode ajudar a obter uma nova visão sobre os processos tecnológicos de extração e tratamento mecânico de materiais vegetais.

Palavras-chave: Química mecânica, flavonóides, quercetina, matérias-primas vegetais

\section{ABSTRACT}

In this paper, we consider mechanical stress resistance of quercetin - 3, 3', 4', 5, 7pentahydroxyflavone in pure substance, in a mixture of crystalline solid quercetin with plant based polymers, and adsorbed on plant based polymers. The plant based polymers were produced by step-by-step chemical removal of components of plant material. The most stable to machine treatment is the quercetin adsorbed on cellulose polymer components, which retain the texture of the original plant tissue. The capability to increase quercetin stability in the process of mechanical treatment changes from hemicellulose via amorphous cellulose to crystalline cellulose. Adsorption on crystalline and amorphous cellulose, which do not retain morphology of plant material, causes reduction in the stability of adsorbed quercetin to a subsequent mechanical treatment. Quercetin that is adsorbed on polyphenolic plant based polymer lignin is the least resistant to mechanical treatment. The understanding of interaction of quercetin and other phenolic compounds with cellulose based matrixes can help to get a new view on technological processes of extraction and mechanical treatment of plant materials.

Keywords: Mechanical chemistry, flavonoids, quercetin, vegetable raw materials 


\section{АННОТАЦИЯ}

Изучена устойчивость к механическому воздействию кверцетина - 3,3',4',5,7 пентагидроксифлавона в чистом виде, в виде смесей твердого кристаллического кверцетина с полимерами растительного сырья и в адсорбированном на растительных полимерах состоянии. Наиболее устойчив к механической обработке кверцетин, адсорбированный на целлюлозных полимерных компонентах сырья, сохраняющих структуру исходной растительной ткани. Способность увеличивать устойчивость адсорбированного кверцетина в процессе механического воздействия изменяется в ряду: гемицеллюлоза > аморфная целлюлоза > кристаллическая целлюлоза. Адсорбция на кристаллической и аморфной целлюлозе, не сохраняющих природную морфологическую структуру, снижает устойчивость адсорбированного кверцетина при последующем механическом воздействии. Кверцетин, адсорбированный на полифенольном полимере растительного сырья - лигнине, наименее устойчив при механической обработке.

Ключевые слова: механохимия, фрлавоноиды, кверцетин, растительное сырье

\section{INTRODUCTION}

Flavonoids are the most widespread type of phenolic minor components of plant raw materials. They have a wide spectrum of biological effects (Clifford and Brown, 2006), and are used as food colorants (Delgado-Vargas et al., 2000) and antioxidants (Willcox et al., 2004). Quercetin - 3, 3', 4', 5, 7-pentahydroxyflavone remains one of the most extensively studied flavonoids. It has antioxidant properties, antiinflammatory action, antihistamine effect, antitumor and antithrombotic activity; it inhibits skin-cell ageing processes and stabilizes cell membranes (Russo et al., 2012).

Plant based phenolic compounds' high reactive capacity to oxygen and free radicals is the basis of the antioxidant action of many flavonoids (Kandaswami and Middleton, 1994). On the other hand, the high speed of oxidation processes poses problems with their extraction from plant raw materials using solvents.

Mechanical treatment of crystalline quercetin mixtures with auxiliary polymers is the method of producing pharmaceutical quercetin formulations. Pre-pulverization of raw materials is a mandatory process before flavonoid extraction. When mechanochemical methods of substance extraction are used (Lomovsky and Lomovsky, 2011), stability and resistance of biologically active substances to mechanical treatment is the cornerstone of success. In the last cases, mechanical treatment is applied to a powder system, which contains both the unstable substance being extracted and plant tissue $90 \%$ of which are bio-polymers. The polymer share of the dried plant material is crystalline and amorphous cellulose, hemicellulose and lignin. Morphologically, the plant tissue structure includes unlignified cells consisting predominantly of cellulose, and lignified cell walls. In the cell wall, extended cellulose fibrils are immersed in a layer of hemicellulose. During lignification, mainly on the outer side of a cell wall, layers shape containing amorphous polyphenolic polymer lignin, which establishes supra-molecular links to carbohydrate components.

Quercetin is found in different kinds of plant material: in fruits, vegetables, medicinal herbs and spices (Sultana and Anwar, 2008; Yang et al., 2008; Wach et al., 2007). The content of the minor component of quercetin in dry plant material does not exceed the amount of several percents.X-ray phase analysis does not reveal crystalline-phase quercetin in plants.It is to be assumed that quercetin is much more likely to be found in the adsorbed form with hydrogen or glycoside bonds to polymers than in the individual phase.

The goal of this study is to investigate the effects of polymeric components of plant raw materials on the resistance/stability of quercetin during their joint mechanical treatment. For this purpose, already known chemical methods were applied to a quercetin-free raw material - wheat straw (Triticum aestivum L.) and hydrolysed lignin produced by the "Baikalsky Pulp and Paper Plant" - in order to obtain polymer components of cell walls of various chemical composition and structure.

Samples of lignocellulosic plant based polymers - wheat straw - have a homogeneous structure (Liu, 2005) and demonstrate the average composition of key 
structural components (cellulose, hemicellulose and lignin) typical of other kinds of plant materials (Prasad, et al., 2007), which makes wheat straw quite convenient as a model object for investigation. The original stock of straw contains nearly $20 \%$ of extractable substances all of which were removed before the tests. The resulting samples contained solely plant based polymers: cellulose (39 $\pm 2 \%)$, hemicellulose (40 $\pm 2 \%)$, lignin $(21 \pm 1)$.

The original stock of industrial lignin contains many soluble substances. Due to this fact, before putting it to use, lignin was extracted with water and ethanol at the solid-to-liquid ratio of $1 / 50$, in an ultrasonic bath, the material was processed 12 times for $1800 \mathrm{sec}$ each, by each solvent, till all soluble substances were removed.

\section{MATERIALS AND METHODS}

\section{The experimental part of the study}

For comparison, two groups of samples were prepared: a) physical mixtures of crystalline quercetin with polymeric powders, and b) samples containing adsorbed quercetin. After the samples were subjected to mechanical treatment for the fixed time intervals, quercetin was isolated and its desorption kinetics was measured, after which it became possible to make conclusions on the effects plant based polymers have upon the resistance of quercetin to mechanical effect.

The mechanical treatment of crystalline quercetin and vegetable materials were performed in a planetary centrifugal mill-activator AGO-2 (JSC "Novic", Novosibirsk, Russia) followed by water cooling using steel drums and balls. The load of steel balls (diameter $=5 \mathrm{~mm}$ ) in drums was $200 \mathrm{~g}$, the load of the sample being worked on was $10 \mathrm{~g}$, treatment time $0-30 \mathrm{~min}$, calculated ball acceleration $20 \mathrm{~g}(200 \mathrm{~m} / \mathrm{sec} 2)$. In order to reduce temperature rise effects upon the sample being treated, the mill was stopped every $5 \mathrm{~min}$ for another $5 \mathrm{~min}$, and the reactor was cooled down.

\section{HPLC analysis}

Under experimental conditions, it is possible that quercetin will be oxidized by air oxygen and by various radical particles released during mechanical treatment of polymers. When reacting with free radicals, quercetin oxidizes through a sequential transfer of one or two atoms of hydrogen, which leads to the forming of a semiquinone radical and quinone, respectively. The semiquinone radical can enter into a reaction producing quinone with its subsequent degradation (Zhou et al., 2008). Oxidation by oxygen leads to oxidative breakdown (Zenkevich et al., 2007).

The amount of flavonoids desorbed from polymers was measured by HPLC (high performance liquid chromatography) using Milichrome A-02 device (LLC "EcoNova", Novosibirsk, Russia). They were detected with UV-detector $(260 \mathrm{~nm})$. As a stationary phase in the column, ProntoSil 120-5-C18 was used, with sorbing particle size of $5 \mu \mathrm{m}$. Elution proceeded in the gradient mode (Mizukami et al., 2007). The solvents used included: eluent A - distilled water, $\mathrm{B}$ - acetonitrile. Operation mode: regeneration $500 \mathrm{mcl} 5 \% \mathrm{~B}$; analysis: $0-4000$ $4300 \mathrm{mcl}, 5-100-100 \% \mathrm{~B}$. Eluent injection rate was $100 \mathrm{mcl} / \mathrm{min}$. Detection limits were $0.1-1.6$ $\mathrm{mg} / \mathrm{ml}$.As the standard, Quercetin hydrate $\geq 95$ $\%$, Sigma-Aldrich, was used.

\section{Determining chemical composition and obtaining polymers from lignocellulosic raw materials}

By procedure described in (Bychkov et al., 2012), the content of components was determined by residue after drying up at $105^{\circ} \mathrm{C}$ for 8 hours.

Lignocellulose was obtained from plant matter dispersion with particles sized $2-3 \mathrm{~mm}$ by removing the extractable substances through a sequential exhaustive extraction by hexane and water. For that, a solvent was added at the solidto-liquid ratio of $1 / 50$ to a weighted test sample, and carried out extraction in an ultrasound bath for $20 \mathrm{~min}$. When the ultrasonic treatment was over, the resulting extract was drained. The procedure was repeated 3 times for each of the solvents. The resulting lignocellulose was then dried up at $105^{\circ} \mathrm{C}$ to reach the constant weight.

Lignocellulose without hemicellulose was obtained from lignocellulose by the method of diluted acid hydrolysis. For this, a weighed test sample of lignocellulose was soaked in sulphur acid at $S / L=1 / 25$ and thermostated at $95^{\circ} \mathrm{C}$ for 5 
hours, with intermittent mixing. Solid residue was separated by filtering, the rest of sulphur acid removed by rinsing in dilute $(0.33 \%)$ ammonium hydroxide to neutral/faintly alkaline reaction of the washing solution. Then it was washed with water and dried up at $105^{\circ} \mathrm{C}$ to constant weight.

Native cellulose retaining the texture of the original raw material was obtained from lignocellulose without hemicellulose by removing lignin, by the method of hydrogen peroxide oxidation in an alkaline solution. For this, lignocellulose without hemicellulose was soaked in $2 \%$ hydrogen peroxide at $\mathrm{S} / \mathrm{L}=1 / 25, \mathrm{pH}$ was brought to 11.5 by adding $1 \mathrm{M}$ of $\mathrm{NaOH}$ and thermostating at $80^{\circ} \mathrm{C}$ for 1 hour. The solution was intermittently mixed. Upon delignification, the solution was filtered, solid residue washed away by diluted $1 \%$ acetic acid to neutral/faintly alkaline reaction of the washing solution. Then the residue was washed with water and dried up at $105^{\circ} \mathrm{C}$ to reach the constant weight.

To mechanically amorphize cellulose, the weighed sample was mechanically treated by the method described above. The treatment time was 1800 sec. Crystallinity was controlled by the Xray difraction method, crystallinity index calculated by the Segal formula (Segal et al., 1959).

\section{Methods of adsorption and desorption of} quercetin on polymers

To a saturated solution of quercetin in ethanol $(8 \mathrm{mg} / \mathrm{ml})$ a weighed sample of matrix powder was added. Upon adsorption for 2 hours, polymer particles were filtered out. At this, the powder took the yellow colour characteristic of quercetin. Then exhaustive repeated desorption of quercetin by ethanol was carried out. Quercetin content in the solutions was controlled by HPLC. By the 7th desorption cycle, concentration of quercetin in the solution was below detection threshold, which testifies to the fullness of extraction. At this stage, polymers regain their natural white colour.

\section{RESULTS AND DISCUSSION}

Polymeric samples of different composition have different quercetin sorption capacity. For meaningful comparison of the resulting data, quercetin concentration in the sample was normalized by quercetin content before mechanical treatment. Data on quercetin degradation kinetics under mechanical treatment are presented on figure 1.

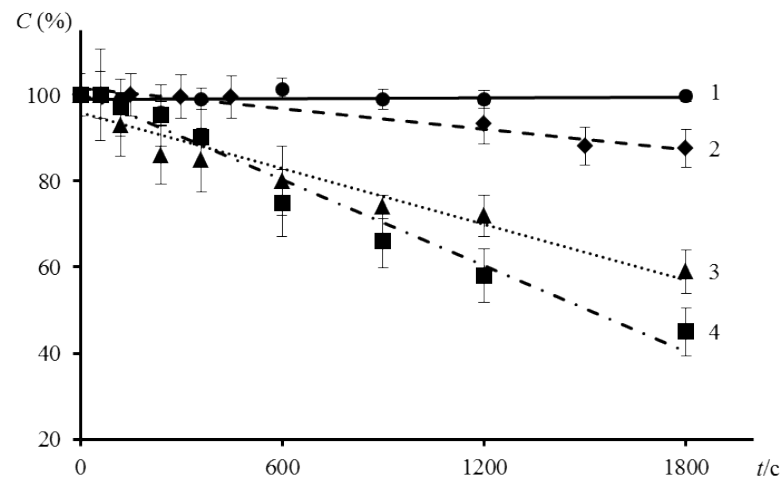

Figure 1. Quercetin concentration dependence on the duration of mechanical treatment: 1 - quercetin adsorbed on a lignocellulosic matrix made of straw; 2 quercetin as a single phase (standard); 3 quercetin in a physical mixture with crystalline cellulose; 4 - quercetin adsorbed on crystalline cellulose

As a value that characterizes quercetin stability, the amount of substance which is desorbed from the samples after $1800 \mathrm{sec}$ of mechanical treatment, related to the initial amount, was chosen. The results are presented on figure 2 .

Crystalline quercetin under mechanical treatment in the absence of polymers degrades by $10 \%$ in $1800 \mathrm{sec}$ (Figure 2a). In the presence of crystalline cellulose (Figure $2 b, c$ ), the stability of quercetin in the sample decreases in comparison with isolated quercetin regardless of the form of quercetin presence. In the presence of lignocellulose (Figure 2d), the resistance of quercetin in a physical mixture being mechanically treated remains the same, while its adsorption on a lignocellulosic matrix leads to a greater stability (Figure 2e). A comparison of samples having the same chemical content of polymers but different ways of quercetin deposition (Figure 2b,c,d,e) shows that the samples where quercetin is in the sorbed state are more stable under condition of mechanical stress than mixtures of quercetin phases with polymers. 


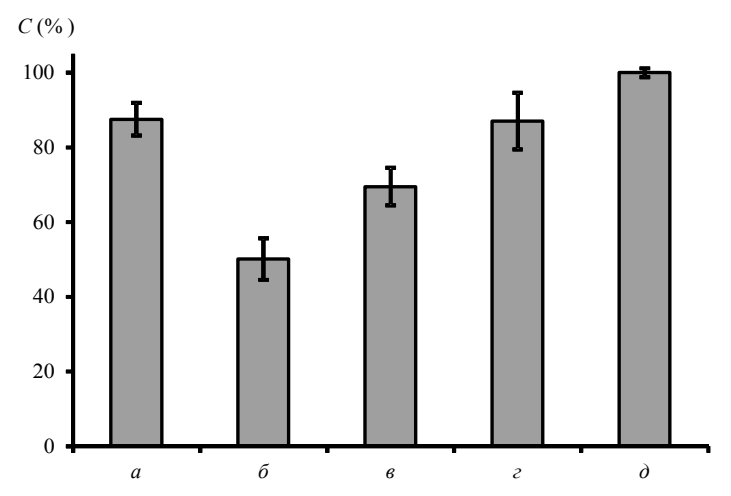

Figure 2. Relative content of quercetin after mechanical treatment of the samples: a quercetin (standard); $b$ - quercetin mixed with crystalline cellulose; c - quercetin adsorbed on crystalline cellulose; $d$ - quercetin mixed with lignocellulose; e - quercetin adsorbed on lignocellulose

It is known (Lomovsky and Lomovsky, 2011) that in the presence of natural matrixes, quercetin stability to mechanical stress is significantly higher than resistance of this compound as a single phase. Since the stabilizing effect is more pronounced in cases when quercetin is adsorbed on plant based polymers, unlike cases when it is present in mixture phases, we may assume that in the initial quercetin and flavonoid-containing raw material the desired substances are also in the sorbed state and not as single phases.

To measure the contribution of each of the cells-wall polymers into the stabilization effect, tests were run on samples where quercetin was adsorbed on individual components of lignocellulose. As sorbents, the chemical agents of different morphology from that of a plant based lignocellulose matrix, were used. The results are presented on figure 3 .

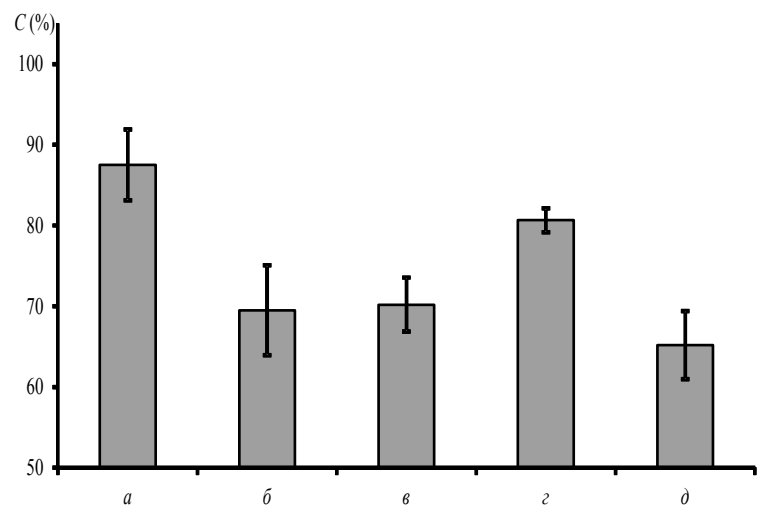

Figure 3. Relative content of quercetin after mechanical treatment of the samples: a quercetin (standard); $b$ - quercetin adsorbed on crystalline cellulose; $c$ - quercetin adsorbed on amorphous cellulose; $d$-quercetin adsorbed on hemicellulose; e - quercetin adsorbed on lignin

The presence of each of the matrix components separately lessens quercetin stability index. The polyphenolic component, lignin, destabilizes quercetin in the most pronounced way. In the case of cellulosic components, the capability to destabilize quercetin resistance properties in the process of mechanical action changes in the following succession: crystalline cellulose $>$ amorphous cellulose $>$ hemicellulose. Hemicellulose being a multi-chain polymer, its destabilizing effect is minimal. It would seem that not only the chemical content of the polymers but also their crystalline structure are responsible for quercetin stabilization under mechanical impact.

By sequential removal of hemicellulose and lignin from plant based lignocellulose, we obtained the samples of polymers that retained the morphology of the initial stock of lignocellulose material. 


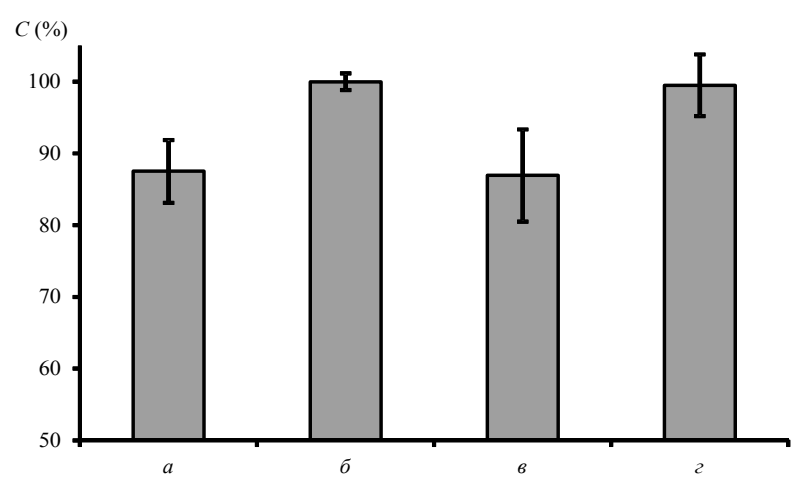

Figure 4. Relative content of quercetin after mechanical treatment of the samples: a quercetin (standard); $b$ - quercetin adsorbed on plant lignocellulose; $c$ - quercetin adsorbed on plant lignocellulose without hemicellulose; $d-$ quercetin adsorbed on a sample without lignin (amorphous-and-crystalline cellulose)

As was demonstrated above, adsorption on plant based lignocellulose increases quercetin resistance to mechanical impact (Figure 4a) in relation to the initial crystalline quercetin. After removal of hemicellulose from plant based lignocellulose, the stabilizing effect for adsorbed quercetin under mechanical effect disappears (Figure 4c). Removal of lignin (Figure 4d) does not alter the stabilizing effect.

It is interesting to note here that quercetin adsorbed on amorphous and crystalline cellulose, which do not possess the texture of the initial plant tissue (Figure 3b,c), demonstrates a lesser resistance to mechanical treatment. Contrary to this, adsorption on cellulose of an amorphouscrystalline structure leads to quercetin stabilization (Figure 4d). The data obtained point to the fact that quercetin stabilization is linked not only to the chemical composition of the plant cellwall polymers but also to the morphology of polymers that are obtained by a sequential removal of polymer components from plant cellwalls.

In order to confirm the assumption about stabilization of quercetin adsorbed by structured polymers, the samples of polymers with the same chemical composition but different morphology were obtained. Some of the samples retained the structure of the initial plant cell-walls, others were subjected to a prolonged mechanical treatment with the aim of deliberately disordering the regularity of polymers. The data are presented on figure 5 .

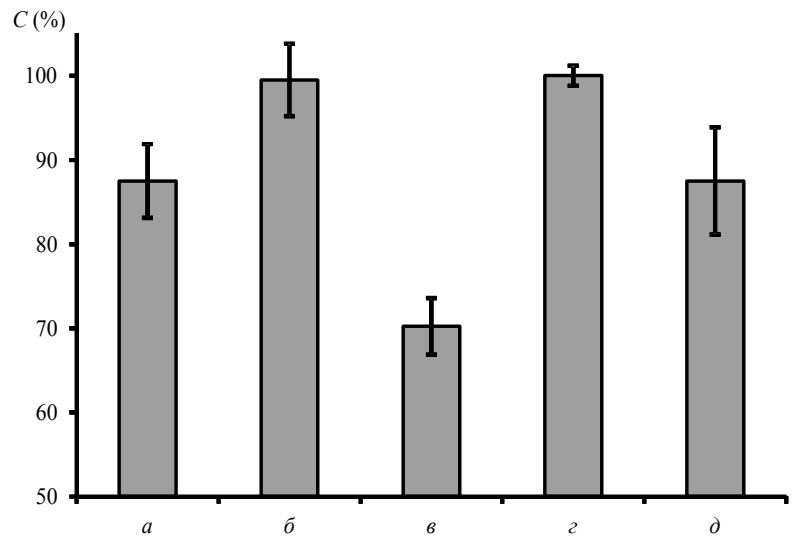

Figure 5. Relative content of quercetin after mechanical treatment of the samples: a quercetin (standard); $b$ - quercetin adsorbed on amorphous-and-crystalline cellulose; $c$ quercetin adsorbed on amorphous cellulose; $d$ quercetin adsorbed on lignocellulose; e quercetin adsorbed on amorphous lignocellulose

The sample where quercetin is adsorbed on lignocellulose, which retains the structure of the initial material (Figure 5d), demonstrates an increase in the stability under mechanical treatment in comparison to crystalline quercetin. In cases where the polymers are deeply disordered and made amorphous (Figure 5e) by a mechanical pre-treatment, the stabilizing effect disappears. For cellulose matrixes, the effect is even more pronounced. Thus, using amorphouscrystalline cellulose isolated from plant raw materials enhances the stability of adsorbed quercetin; at the same time, mechanically amorphized cellulose brings about quercetin destabilization (Figure 5b,c).

The revealed stabilization effect arises after $1800 \mathrm{sec}$ long mechanical treatment. This time is enough, under conditions used in the study, to cause a total disordering of the structure of a crystalline polymer (Avolioa et al., 2012). It may be concluded that the stabilization effect can be accounted for by different interactions between quercetin and crystalline/amorphous matrixes.

\section{CONCLUSIONS}

Mechanical treatment of the powdered quercetin leads to its decomposition and its lesser content in a preparation. When a mixture of the powdered quercetin and lignocellulosic 
material is subjected to mechanical impact, quercetin stability under it remains intact. Quercetin stability under mechanical treatment is influenced by the type of interaction between quercetin and the polymers obtained from lignocellulosic raw materials. The quercetin that is adsorbed on polymers is more resistant than the one in a physical mixture with polymers.

Components of a lignocellulosic matrix made of straw (crystalline cellulose, amorphous cellulose) that do not retain their natural morphology, when used for quercetin adsorption separately, reduce the resistance of adsorbed quercetin to mechanical effect. Adsorption on a polyphenolic component, lignin, destabilizes quercetin to the most considerable degree. In the case of carbohydrate components, the capability to destabilize adsorbed quercetin in the process of mechanical treatment alters in the following succession: crystalline cellulose $>$ amorphous cellulose $>$ hemicellulose. Using the cellulosic matrixes obtained from lignocellulosic raw materials by removing hemicellulose and lignin while retaining its initial natural morphology leads to an increased resistance of adsorbed quercetin to mechanical impact. Quercetin stability under mechanical impact within plant raw materials, while obtaining quercetin preparations mechanochemically, is apparently to be explained by the quercetin adsorbed on a cellulosic component, which retains natural plant morphology, present in the preparations.

\section{ACKNOWLEDGEMENT}

The work was supported by the Russian Science Foundation grant No. 16-13-10200.

\section{REFERENCES}

1. Avolioa R, Bonadiesa I, Capitanib D, Erricoa ME, Gentilea G A multitechnique approach to assess the effect of ball milling on cellulose. Carbohydr. Polym 87(1): 2012, 265-269.

2. Bychkov AL, Ryabchikova El, Korolev KG, Lomovsky OI. Ultrastructural changes of cell walls under intense mechanical treatment of selective plant raw material. Biomass and Bioenergy 47: 2012, 260 267.
3. Clifford MN, Brown JE. Dietary Flavonoids and Health - Broadening the Perspective. In: Andersen ØM, Markham KR. Flavonoids: chemistry, biochemistry and applications (pp. 320-370). CRC Press, Boca Raton. 2006

4. Delgado-Vargas F, Jimenez AR, ParedesLopez O. Natural pigments: carotenoids, anthocyanins, and betalains characteristics, biosynthesis, processing, and stability. Crit Rev Food Sci Nutr 40(3): 2000, 173-289.

5. Kandaswami C, Middleton E Jr. Free radical scavenging and antioxidant activity of plant flavonoids. Adv Exp Med Biol 366: 1994, 351-376.

6. Liu $\mathrm{R}, \mathrm{Yu} H$, Huang $\mathrm{Y}$. Structure and morphology of cellulose in wheat straw. Cellulose 2005, 12(1):25-34.

7. Lomovsky OI, Lomovsky IO. Mechanochemically assisted extraction. In Ed. Lebovka N, Vorobiev E, Chemat F (eds) Enhancing Extraction Processes in the Food Industry. CRC Press, Boca Raton. 2011

8. Mizukami Y, Sawai $Y$, Yamaguchi $Y$. Simultaneous analysis of catechins, gallic acid, strictinin, and purine alkaloids in green tea by using catechol as an internal standard. J. Agric Food Chem 55: 2007, 4957-4964.

9. Prasad S, Singh S, Joshi HC. Ethanol as an alternative fuel from agricultural, industrial and urban residues. Resour Conserv Recycl 50(1): 2007, 1-39.

10. Russo M, Spagnuolo C, Tedesco I, Bilotto $\mathrm{S}$, Russo GL. The flavonoid quercetin in disease prevention and therapy: facts and fancies. Biochem Pharmacol 83(1): 2012, 6-15.

11. Segal L, Creely JJ, Martin AE, Conrad CM. An Empirical Method for Estimating the Degree of Crystallinity of Native Cellulose Using the X-Ray Diffractometer. Textile Research Journal 29(10): 1959, 786-794.

12. Sultana B, Anwar F. Flavonols (kaempeferol, quercetin, myricetin) contents of selected fruits, vegetables and medicinal plants. Food Chem 108(3): 2008, 879-884.

13. Wach A, Pyrzyńska K, Biesaga $M$. Quercetin content in some food and herbal samples. Food Chem, 100(2): 2007, $699-704$. 